\title{
SME firms performance in Nigeria: Competitive advantage and its impact
}

Eniola, Anthony Abiodun $\bowtie$

University of Malaysia, Sarawak (UNIMAS), Malaysia (tony42003@yahoo.co.uk)

Ektebang, Harry

University of Malaysia, Sarawak (UNIMAS), Malaysia (harryentebang@yahoo.com)

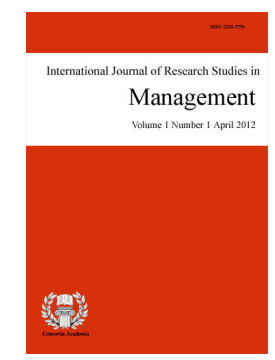

ISSN: $2243-7770$ Online ISSN: 2243-7789

OPEN ACCESS

\section{Abstract}

Small and medium enterprises (SME) performance forms a very important part of the Nigerian economy. The SME sector is a major engine which encourages the growth of jobs and wealth creation in the country's economic system. SMEs performance act as a significant part that is linked to the strengthening and enhancement of the development of the country. The SME performance and growth in manufacturing, agriculture, services, and so on, has been considered as the engine drive and has contributed to the Nigeria economy. Sustainable growth and the increase of SME performance, competitiveness will open numerous doors for employment opportunities, tangible and intangible assets (investment) in the environment. The SME sector has developed rapidly over these years. The major aim of this paper is to look into the SME sustainable competitive advantage and emphasis on its growing importance. Likewise, some guidelines were offered in order for SMEs to reach performance and competitive advantage. In a wider perspective, this paper would provide some available conclusions and concrete recommendations. Besides, this work will serve as an information cause that will promote and orient SMEs performance towards competitive advantage. Through this way, it will contribute to the continuous promotion and active growth of SMEs, as easily to increase the level of the firm's performance and business competitiveness in Nigeria.

Keywords: SMEs; performance; competitive advantage; resource-based view; strategic management 


\section{SME firms performance in Nigeria: Competitive advantage and its impact}

\section{Introduction}

The performance and growth of small and medium enterprises (SMEs) is a major driver and indices for the level of industrialization; modernization; urbanization, gainful and meaningful employment for all those who are able and willing to work, equitable distribution of income, the welfare, income per capital and quality of life enjoyed by the citizenry (Aremu \& Adeyemi, 2011), because SMEs contribute to employment growth at a higher rate than larger firms (Farouk \& Saleh, 2011). The SMEs sector with global recognition is view as an important force of driving the economic growth and employment creation in both developing and developed countries (Ariyo, 2008; Kpleai, 2009); this is well documented (Birch, 1989; Storey, 1994). SMEs (firms with 200 or fewer employees) makes up the largest business sector in every world economy (Culkin \& Smith, 2000), and governments around the globe are increasingly promoting and supporting the SME growth as part of their overall national development strategy (Abdullah \& bin Dakar, 2000). Harrison and Watson (1998), point to the flexibility of SMEs, their simple organizational structure, their low risk and receptivity as the essential features facilitating them to be innovative.

The importance of SMEs in the development of economic, reduction in poverty, increase in employment, output, innovation in technology and uplifting in social status and standard is globally recognized and acknowledged in developing as well as in developing economics. Small and Medium Scale Enterprises have been acknowledged to have a prodigious potential for sustainable Development. It is primarily through the growth of SMEs that employees made redundant by large firms have been absorbed back into the work force (Storey, 1994; Frank \& Landstrom, 1998). Through the multiplier effect, this employment provides income to regions which stimulate local economic activity, in results, drives wealth and further employment generation (Walker \& Webster 2004). In order to compete and sustain successfully, locally, and globally, micro, small and medium enterprises must not only be perfect in their area, but also conserve eventually.

Evenly component of business management, performance management can be one of the biggest challenges faced by businesses in the SME sector, particularly with respect to their survival and competitive advantage. If management is not trained and educated on how to manage finance, Mbonyane (2006) noted that small businesses fail and did not succeed because more often than not cash flow is not properly managed. Performance is from the aspect of financial and non-financial, the main elements of which consist of "sales-based and firm-based." Empirically, it is found that there is a significant relationship between competitive advantage and the sales-based performance of organizations. Profitability, growth, productivity, level of sales revenue, market share and product, return on investments, product added value is used in the measurement of Sales-based performance (Falshaw et al., 2006; Murphy et al., 1996; Wang \& Lo, 2003; Brush \& Vanderwerf, 1992; Neely, 2005; Spivey \& McMillan, 2002). In addition, other previous studies have also further illustrated that there is a significant relationship between competitive advantage and firm-based performance of organizations. Firm-based performance is measured in terms of the emphasis on employee development, customer satisfaction, job satisfaction and efficient organizational internal processes (Murphy et. al., 1996; Neely, 2005; Spivey \& McMillan, 2002; Wang \& Lo, 2003).

In Nigeria the importance and performance contributions of Small and medium scale business as a creator of employment, in particular, those with low skill level, is widely recognized. In 2002, $98 \%$ of all businesses in the manufacturing sector were SMEs operating in Nigeria, providing $76 \%$ of the workforce and $48 \%$ of all industrial output in terms of value added (Mahmoud, 2005; Odeyemi, 2003; SMEDAN, 2006). SME employs 87.9\% of the workforce in the private sector (Kadiri, 2012; Russell Olukayode \& Christopher Somoye, 2013). In the agriculture and manufacturing sectors, SMEs employ more than $80 \%$ of the total workforce. In the last few years, an increase in employment of SMEs has exceeded the increase in their contribution to GDP, highlighting the 
employment creation potential of this sector of the economy (Killian et al., 2007).

During the transition period of civilian government in Nigeria, a lot of new businesses sprang up. Most of them now faced new threats, challenges and crises as an outcome of sustainable competitive advantage within and outside; how are they going to manage to face them successfully? This paper will help to increase the understanding of the traits that make some firms, sustainable competitive advantages with emphasis on its growing importance. As well as reviewing why some firms are able to perform in a diverse economic circle, while others do not (Garnsey, 1996). Despite the widespread practical and academic interest in SME firm's overall economic performance, review studies and the impact of competitive advantage of SMEs firm performance in Nigeria are minimal, so the focal point of this study.

\section{Definition of SMEs}

According to the Organization for Economic Cooperation and Development (OECD), the characteristics of SMEs not only reflect the economic patterns of the country but also the social and cultural dimensions. These differing patterns are noticeable reflected within different definitions and criteria of SMEs adopted by different countries. Whereas some refer to the number of employees as their distinctive criteria for defining SMEs, others use invested capital, and some other use a combination of the number of employees, invested capital, sales and industry type (Dababneh \& Tukan, 2007).

Table 1

Definition of SME by Nigerian Institution

\begin{tabular}{llllllllll}
\hline \multicolumn{1}{c}{ Parameters } & \multicolumn{3}{c}{ Total Assets $\left(\mathrm{N}^{`} \mathrm{~m}\right)$} & \multicolumn{3}{c}{ Annual Turnover $\left(\mathrm{N}^{`} \mathrm{~m}\right)$} & \multicolumn{3}{c}{ No of Employees } \\
\hline Nigerian Institution & $\mathrm{MSE}$ & $\mathrm{SSE}$ & $\mathrm{ME}$ & $\mathrm{MSE}$ & $\mathrm{SSE}$ & $\mathrm{ME}$ & $\mathrm{MSE}$ & $\mathrm{SSE}$ & $\mathrm{ME}$ \\
Fed. Min. of Industries & $<200$ & $<50$ & $\mathrm{Na}$ & $\mathrm{Na}$ & $\mathrm{Na}$ & $\mathrm{Na}$ & $<30$ & $<10$ & $<10$ \\
Central Bank & $<150$ & $<1$ & $\mathrm{Na}$ & $<150$ & $<1$ & $\mathrm{Na}$ & $<10$ & $<50$ & $\mathrm{Na}$ \\
NERFUND & $\mathrm{Na}$ & $<10$ & $\mathrm{Na}$ & $\mathrm{Na}$ & $\mathrm{Na}$ & $\mathrm{Na}$ & $\mathrm{Na}$ & $\mathrm{Na}$ & $\mathrm{Na}$ \\
NASSI & $\mathrm{Na}$ & $<40$ & $<1$ & $\mathrm{Na}$ & $<40$ & $\mathrm{Na}$ & $\mathrm{Na}$ & $3-35$ & $\mathrm{Na}$ \\
NASME & $<150$ & $<50$ & $<1$ & $<500$ & $<100$ & $<10$ & $<100$ & $<50$ & $<10$ \\
Nigeria Industrial Policy & $\mathrm{Na}$ & $\mathrm{Na}$ & $\mathrm{Na}$ & $\mathrm{Na}$ & $\mathrm{Na}$ & $\mathrm{Na}$ & $\mathrm{Na}$ & $\mathrm{Na}$ & $\mathrm{Na}$ \\
\hline
\end{tabular}

Source: World Bank, SME Country Mapping (2001). National Council of Industry under the Ministry of Industry

NERFUND: National Economic Reconstruction Fund

NASSI: National Association of Small Scale Industrialists

NASME: National Association of Small and Medium Enterprises

Despite the disparity in the comparative definitions of SMEs, the enterprises have some common characteristics, of which the foremost is that ownership and management are borne by one individual/ family (Scott, \& Bruce, 1987) and therefore, decisions are often subjective. Secondly, SMEs require small capital base in general, disregarding of the industry and the country where they are based. Nevertheless, they are often having difficulty in attracting funds for expansion as a resolution of which they have to bank heavily on personal sources.

Thirdly, in practice, the management proprietor hardly differentiates his personal fund from the company's funds and this largely contributes to the inefficiency and non-functioning of many SMEs. For them, most SMEs operate with labor intensive technology. They find it less easy to shift from one product line to something radically different; in fact, most SMEs tie their objectives more closely to the product line than in other matters such as the use of capital. In most SMEs there is less organizational differentiation, higher employee turnover and higher labor investment ratio. Lastly, the rate of business dearth is high, probably due to reasons of low capital, lack of relationship between business life and that of promoter, inadequate market information and low level of operation, amongst other factors (Nweze, 2009).

\section{The Impact of SME Performance in the Economy}

The proportion of Nigerian SMEs and their impact on the economy is pretty much similar to some 
developing and developed countries. Nigeria SMEs is playing a very important and the major role in the development of the economy, particularly in the manufacturing sectors. Studies done by the Federal Office of Statistics shows that $97 \%$ of all businesses in Nigeria employ less than 100 employees. The earlier definition of SMEs shows that $97 \%$ of all businesses in Nigeria are, to use the term, small business. The SME sector provides, on average, $50 \%$ of Nigeria's employment, and 50\% of its industrial output (Ariyo, 2005).

SMEs comprise $70 \%$ to $90 \%$ of the business establishment in the manufacturing sector in Nigeria (Oyelaran - Oyeyinka, 2010; Frimpong, 2013). SMEs provide over 90\% of employment opportunities available in the manufacturing sector and account for about $70 \%$ of aggregate employment created per annum. Moreover, to the potential of SMEs to serve as an bedrock for entrepreneurial skills development, even distribution of income, wealth creation, employment generation, and sustainable economic development; SMEs in Nigeria is seen as the creativity and ingenuity of entrepreneurs in the utilization of the abundant non- oil, natural resources of this nation will provide a sustainable platform and spring board for industrial development and economic growth as is the case in the industrialized and economically developed societies (Schmiemann, 2008; Ebiringa, 2011; Onwumere, 2000)

A survey conducted by the Federal Bureau of Statistics (FBS) across the 36 states of the federation and the Federal Capital Territory (FCT) analyzed by the Minister of Trade and Commerce, Olusegun Aganga; shown that there was a total of 17.28 million SMEs in the country out of which 17.26 million are micro enterprises valued at less than N5 million (This Day Newspaper, July 20, 2012; NBS, 2012). It shows micro businesses had an increase in some states, and it shows that micro enterprises represent about 99 per cent of MSMEs in the country. The performance of the SMEs differs from country to country and from one type of business to another.

Lagos State had the highest number of SMEs in the country with 17 per cent of the national figure, followed closely by Kano State, with Osun state hosting the fewest SMEs with only 0.4 percent of the national figure (This Day Newspaper, July 20, 2012; NBS, 2012). From the percentage of micro, small and medium enterprises in the Nigerian economy, it can be seen that micro enterprises constitute the dominant enterprises in this economy. It testifies to the fact that SMEs and especially micro enterprises have the majority of the workforce. SMEs in general play a key role in the economy.

\section{The Importance of the SMEs Performance}

SMEs play an important role as a breeding ground for entrepreneurs and a provider of solutions to address the problems of unemployment, job creation, innovation and long-term economic development (Baard \& van den Berg, 2004; Molapo, 2007; white paper 1995; Storey, 1994). Their role is to provide jobs for the unemployed and entrepreneurial opportunities for individuals who want to venture into businesses. "Small is profitable in Nigeria"; the performance and role of SMEs going forward are bound to be even greater and more pervasive with a demonstrable impact on the emerging world trading order. SMEs have to recognize what their resources are and they need to know how to utilize them, flex them into an advantage for their business. Nevertheless, in the frame of the world-wide economy, SMEs cannot compete by simply looking at the cost and by just cutting it; they must compete on the foundation of knowledge and the value added (Bahiti, 2008). The development of SMEs is an indispensable component in the growth strategy of most economies and holds particular significance.

The performance and development of Small and Medium Sized Enterprises (SMEs) has throughout the world, been of great interest to, among others, development economists, entrepreneurs, governments, venture capital firms, financial institutions and non-governmental organisations (Baker, 1992). Performance management involves establishment of a shared understanding about what is to be achieved, how it is to be achieved; and an approach to managing people that increases the probability of achieving success within an agreed framework of planned goals, standards and individual and team competence requirements (Armstrong \& Baron, 1998). Performance is from the aspect of tangible and intangible resources 


\section{Mixed theories pertaining to Competitive Advantage}

RBV has been widely used in the business management literature as well as in entrepreneurship. In fact, some scholars argued that "at present, the resource-based theory of the firm is perhaps the most influential framework for understanding strategic management" (Barney, Wright, \& Ketchen Jr., 2001, p. 625). Strategic management is especially often asserted important just for the corporation, and it has happened that the manager of the SME did not pay the right attention to the strategic management of the SME.

Competitive advantage is a base for a good strategy, and a good one creates competitive advantage (Analoui, \& Karami, 2003). Another group of scholars focused on examining specific resources which give rise to sustainable competitive advantages. The resources they examined included: response lags (Lippman \& Rumel, 1982), routines (Nelson \& Winter, 1982), functionally based distinctive competencies (Hitt \& Ireland, 1985, 1986; Hitt, Ireland, \& Palia, 1982; Hitt, Ireland, \& Stadter, 1982; Snow \& Hrebiniak, 1980), unique combination of business experience (Huff, 1982; Prahalad \& Bettis, 1986; Spender, 1989), organizational culture (Barney, 1986b; Fiol, 1991), invisible assets that by their nature are difficult to imitate (Itami, 1987), organizational learning (Teece, Pisano, \& Shuen, 1997), entrepreneurship (Nelson, 1991; Rumelt, 1987), and human resources (Amit \& Schoemaker, 1993), among others.

In 1991, Barney, presented a more concrete and comprehensive framework to identify the needed characteristics of firm resources in order to generate sustainable competitive advantages (Barney, 1991). Four criteria were proposed to assess the economic implications of the resources: value, rareness, inimitability, and substitutability. Value refers to the extent to which the firm's combination of potential resources and fits with the external environment so that the firm can exploit opportunities and or neutralize threats in the competitive environment. Rareness refers to the physical or perceived physical rareness of the resources in the factor markets. Inimitability is the continuation of imperfect factor markets via information asymmetry such that resources cannot be obtained or recreated by other firms without a cost disadvantage. Finally, the framework also considers whether the organizations are substitutable by competitors. Hunt and Morgan (1996) proposed that potential resources can be most usefully categorized as financial, physical, legal, human, organizational, informational, and relational.

The importance of a competitive advantage increased these last decades (Hamilton, 2003). Competitive advantage considered as objective of the strategy. Porter (1985), a firm has a competitive advantage when it can create more economic value than its rivals (Barney \& Hesterly 2010) do. Porter's (1985) arguments reflect the strengths, weaknesses, opportunities, and threats (SWOT) of the framework for assessing competitive advantage. Competitive advantages are those factors that a firm needs to have in order to succeed in business (Analoui, \& Karami, 2003). There are three types of competitive advantage; the cost of leadership, differentiation and focus (Porter, 1985). Lynch, (2006) argued that each of these three strategic options represents an area that every business and many not-for-profit organizations can usefully explore and every business needs to choose one of these in order to compete in the marketplace and gain sustainable competitive advantage. Lynch (2006) also stated that the general principles can perhaps be applied to public service and not-for-profit organizations where they compete for resources, such as government funding of SMEs. Consequently, some strategic management researchers are advocating the importance of dynamic core competencies (Lei et al., 1996) or the understanding of firms' market positions from a dynamic theoretical perspective (Porter, 1991)

Unique competencies help a firm stand out in its markets when its competencies are superior to its competitors (Andrew, 1971). Unique resources are those resources that can create sustained competitive advantage for a firm. These resources are distinctive or unique capabilities specific to particular organizations and cannot be imitated. Core competencies and distinctive competence are two main factors that induce SMEs to have a competitive advantage. Core Competences are the skills and abilities by which resources are deployed through the organization's activities and processes in such a way as to achieve competitive advantage in ways that cannot be imitated or obtained by others. (Johnson et al., 2010, p. 65) Competitive advantage is important 
Eniola, A. A. \& Ektebang, H.

for businesses. Only the firms with superior performance skills are bestowed with core competencies while another firm needs to acquire them in order to stand in the competition. Not all businesses have a competitive advantage; however, they have to find ways to have it. A competitive advantage is a concept of special importance.

\section{Sources of Competitive Advantage}

A firm that formulates and implements a strategy that leads to superior performance relative to other competitors in the same industry or the industry average has a competitive advantage. On the one hand, it is important for SMEs to obtain, maintain and increase the competitive advantage through the internal and external financial resources they may have and insure. Henry Mintzberg (1973) classified ten managerial roles into three categories: interpersonal, informational, and decisional. Mintzberg's general portrayal of managerial work for competitive advantage was confirmed in later studies (Kotter, 1982; Tsui, 1984). On the other hand, SMEs have to do the external analysis to identify the opportunities and threats and to do an internal analysis: to identify the distinctive competencies. According to Resource - based theory, in-depth-time competitiveness of a firm depends on the resources it possesses that differentiate it from its competitors and are durable and difficult to imitate and substitute (Zaridis, 2009).

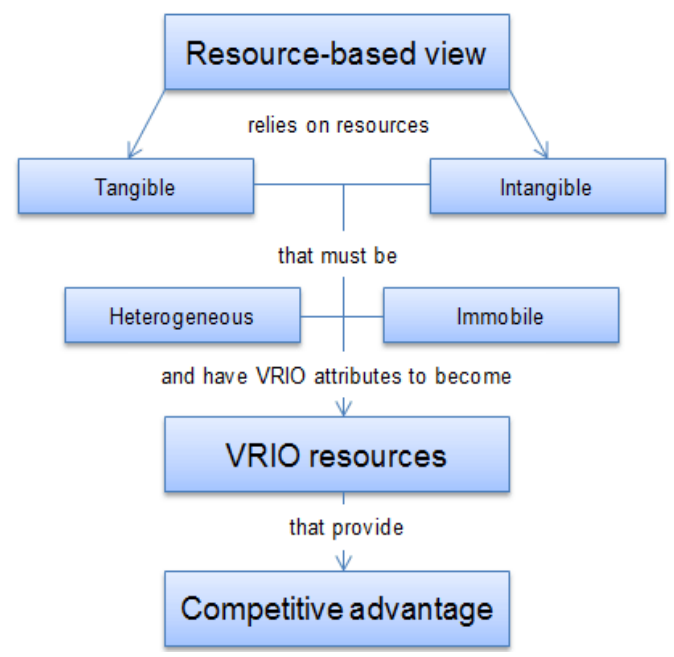

Source: Ovidijus, J. (2013)

Figure 1. Model Explains RBV and Competitive Advantage

The RBV posits that the improvements of firm performance depend on the availability of, access to, valuable, rare, inimitable, non-substitutable and relatively immobile resources or resource bundles (Barney 1991). Wernerfelt (1984, p. 172) posits that resources are "anything that might be thought of as a strength or weakness of a given firm," comprising tangible and intangible assets. Tangible resources include financial capital (e.g. equity capital, debt capital, retained earnings) and physical capital (e.g. machinery \& buildings). While intangible resources such as organization culture, learning, networks, and reputation tended to be tacit, idiosyncratic, and deeply embedded in the organization's social fabric and are more likely to produce a competitive advantage (Winter 1987). According to RBV proponents, it is much more feasible to exploit external opportunities using existing resources in a new way rather than trying to acquire new skills for each different opportunity. In RBV model, resources are given a major role in helping companies to achieve higher organizational performance. Developing earlier work by Wernerfelt (1984), and Rumelt (1984), Barney (1991), the most prominent proponent of the RBV, proposed that a firm use of ,idiosyncratic, immobilece resources are the source of sustained competitive advantage. 
SME firms performance in Nigeria: Competitive advantage and its impact

Table 2

Classification of Resources

\begin{tabular}{ll}
\hline \multicolumn{1}{c}{ Tangible resources } & \multicolumn{1}{c}{ Intangible resources } \\
\hline Financial & Human \\
Firm's borrowing capacity & Experience and capabilities of employees \\
Firm's capacity to raise equity & Trust \\
Firm's cash account and cash in hand & Managerial skills \\
& Practices and procedures
\end{tabular}

Physical

Modern plan and facilities

Favorable manufacturing locations

State of the art machinery and equipment

Technological

Trade

Innovative production processes

Organizational

Strategic planning processes

Excellent evaluation and control systems

\author{
Innovation and creativity \\ Technical and scientific skills \\ Innovation capacities
}

Reputation

Reputation with customers

Reputation with suppliers

Brand name

Source: Dess et al. (2007); Kraja and Osmani (2013)

The RBV of the firm predicts that certain types of resources SMEs firm owns and controls have the potential and promise to generate competitive advantage, which eventually leads to superior firm performance. Financial resources such as cash-in-hand, bank deposits and or savings and financial capital explain the level of firm competitive advantage and performance (Morgan et al., 2004; Ainuddin et al., 2007). Current research in both strategic management and finance has begun to examine the relationship between firm strategy and its capital structure (Ravid, 1988; Chatterjee \& Wernerfelt, 1991). In a study of Brander and Lewis (1986); Gertner, Gibbons, and Scharfstein, (1988) and Williamson, (1988) suggests that the two aspects of a firm may be closely linked with each other. Balakrishnan and Fox, (1993 p. 3), state that "firm's ability to manage its relationships with lenders... becomes a key source of competitive advantage." Most theories of capital structure, however, ignore the role of the suppliers of financial resources. Physical resources such as the production technology, machinery, equipment, plant and capacity contribute positively towards SMEs competitive advantage and eventually result in superior firm performance (Ainuddin et al., 2007; Morgan et al., 2004). Moreover, Human resources in terms of experience and capabilities, trust, managerial skills, practices and procedures of top and middle management, administrative and production employees were also able to elucidate the extent of firm competitive advantage and the resulting SME firm performance (Adner \& Helfat, 2003; Morgan et al., 2004; Datta et al., 2005; Ainuddin et al., 2007; Abdullah et al., 2007a; Rose \& Kumar, 2007). Experiential resources such as product reputation, manufacturing experience and brand name can account for the variation in firm competitive advantage and performance (Morgan et al., 2004; Ainuddin et al., 2007). In short, SME firm resources are the base for attaining and maintaining competitive advantage.

Although, competitive advantage is more likely to spring from intangible rather than tangible resources, because tangible resources can easily be bought in the market so they confer little advantage to the companies in the long run because rivals can soon acquire the identical assets. Therefore, RBV is more relevance in the field of SME resourcing because of the importance of intangible resources of managerial competence and experiential knowledge in developing competitive advantage. These resources are especially important in SMEs because resource constraints preclude the procurement of this talent outside the organization.

On that point are some sources of advantage in the systems. They are high performance or technology, quality, niche marketing, differentiation, low costs, quality, synergy, service, and vertical integration; culture, leadership and style (Lynch, 2000). Also, it is important for SME owners and managers to know (Goldsmith 
1995), how to keep in a match among those external and internal factors; pay ongoing attention to external factors- technological, economic, political and social components. According to Kume and Leskaj (2010), in the incoming years, the competitive advantage may take in its roots based on; Service added in products; skilled and trained staff in the long run; continuous improvement of the product and services; distinctive competencies and quick answers.

\section{SMEs Performance in Nigeria: Issues Related}

The RBV through its insights into the nature of competitive advantage explains why some resources are more advantage generating than others and discussing the role of a manager in resource deployment. Therefore, the view indicates how advantages persist for some firms even in periods of open competition like the ones raging in Nigeria. One of the assumptions of this study is that it can validate and contribute to the performance view of SMEs, and the role competitive advantage has on the firm's performance. The perspective's contribution to this paper context is also framed in the entrepreneurship literature.

Most SMEs in Nigeria in terms of performance is proving to produce competitive advantage through differentiation while some are producing it through cost. At the outset, the SMEs did not yield the proper attention to the foundation of competitive advantage, but things have changed for good. Today, they are performing their best. Some of the Nigeria SMEs succeed, and some fail because there is a set of problems, such as the financial factor, strategic management factor, management experience factor, marketing factor, applied science and innovation factor, and many others.

Financial Factor is related to resources that can enhance the performance and growth for SMEs. The nonperformance and high rates of failure among SMEs in the country are due to operating of SMEs in a non-conducive financial planning environment through high-interest rate, high-collateral demand, difficulties in accessing information and lack of market exposure. The financial planning environment should conducive for the SMEs firm owners to create a track, and monitor business plans and forecasts in real time, and consolidate forecasts by geography and product for potential expansion in order to increase the borrowing capacity. As Penrose (1959:39) stated " there is a relation between entrepreneurial, competitive advantage and the finance a firm can attract, and that difficulty attributed to lack of capital may often be related to the existence of entrepreneurial services.

Strategic management factor is linked to the fact that it often happens to start a business without accepting a scheme of how to realize the great idea. Apparently, this mindset needs to be changed and for things to improve. Besides, it's imperative that businesses don't remain complacent in their approaches to planning. Business that fail to drive planning practices and tools forward will stay bound by slow, stovepipe planning processes, finding it difficult to compete with more-nimble and unified systems that are a lot more adept at leveraging their resources

Reynolds and Miller (1992), one of the key factors for fully developed new firm, is a full time commitment of the owner-manager and subordinates. Castanias and Helfat (1991); Spender (1993); Lei and Hitt (1995); Conner and Prahalad (1996) noted that human resource factors form one of the most significant areas for successful performance of the company to be competitive. Most SMEs in the country are finding it difficult in employing right hand because of family overbearing. To be the member of the business family does not suffice; what counts a lot is to recruit the correct person; full of experience, the skills and the capability to do the job and perform perfectly. In realizing this, the organizations have to regard their staff as valuable resources. Successful establishments have to create space to their staff, in order that they could act their best and showoff their skills. Sometimes, for most businesses, human resources are the main resources that SME probably have. Understanding and managing their human resources and their culture is seen as a competitive advantage by them.

Nigeria SMEs rely on more traditional labor rather than use of modern technology due to lack of enough 
capital or sheer ignorance of technological advances. Most SMEs manages their business with the traditional approach that results in low performance in terms of productivity, low-quality products to small and local market. It is noted that use of a traditional approach by SMEs tend to have effect on low productivity and, as a result, are weak in terms of competition related. Significant fact is that innovation doesn't come from a single person. It comes from the business itself. Innovation is there, but someone in collaboration with others has to bring it. It can only happen when there is incentive support and freedom within and outside the firm for self-expression then, there is often a good will.

The assumption is if the potential customers are not aware of your products or services no one will do business with you (Scheers, 2010). Lack of customer's demand is what businesses have to take. There is also, ample research evidence to prove that marketing plays a significant role in the performance of SMEs for competitive advantage. The SMEs manager should first involve in identifying what the customer needs are and translate them into the planning of a new product or a new service. Knowing customers' need about a product or service helps them to satisfy customers' expectations. Inadequate marketing skills of owners create marketing problems in the small business sector. Customers' expectations are continuously increasing; companies are instantly demanded to work beyond their primary need of satisfying the customer, they are exceeding the expectations to delight the client (Kraja \& Osmani, 2013). Gilmore et al. (2001) reviews marketing limitations of SME as limited resources (such as financial, time and marketing knowledge), Micro, Small and Medium Enterprises do not possess enough ability to manage the technology (Wang \& Wu, 2011). In Nigeria, SMEs performances are faced with a lack of marketing skills.

Mahmood (2008), role of corporate governance is also an essential factor for SMEs performance, sustainability and competitive advantage. Corporate governance is all about the individual roles of the shareholders as owners and the managers. It is about policies that encourage and stimulate the development of SMEs and economic sectors, in order that they could make best use of potential resources. Also, it is about establishing and following rules and procedures to manage and run an enterprise, setting up a system of checks and balances to stop abuses of authority and to ensure the integrity of financial statements (Eniola, 2014). Hence, despite improvements and the advancement that this sector has experienced during this period, the performance of SMEs in the country is still confronting a lot of difficulties.

\section{Recommendations and Conclusion}

From the literature review; organizational competitive advantage from the RBV is indeed consequential as it can be used as a conceptual measure for SMEs performance in particular through application and manipulation of identifying internal and external organizational resources to raise their competitive advantageous position. Financing provision, inadequate management, lack of initiative and lack of managerial education are some reasons why SMEs are not capable of sustaining a competitive advantage. SMEs face challenges and to successfully manage those.

The owner-managers have to strategy and strategies by further enhance their aggregate resources, especially tangible and intangible resources. Spending more time with the management of their business, because this will aid in understanding the current position, (both financial and non-financial), and to make safe steps towards the hereafter. Managers have to be mindful of what they are doing. That is in attaining competitive advantage, there should be dilute ownership and control of the business. Human resources should be strengthened by employing competent and professional's persons that have the expertise, skills and capacity to share with the other members of the business. If it is too important to choose the right person who knows how to run a business, incentive and welfare motivation should be given to encourage them to perform the job well

Also, possible policy intervention by the government through fiscal measures, tax incentives or financial initiatives is a way to improve the perceived magnitude of importance of financial policy in their relationship with performance and in realising the firm valuable resources. The value - creation process depends on the 
translation of competitive dynamics into sustainable cash flows. A necessary condition for the value inherent in strategic assets to lead to increased firm value is suitable for financing provision decisions. SMEs should try to use or attain the best benefits from government policy or initiatives.

SWOT analysis has to be done by the SMEs owners- manager in the light of objectivity to determine if things are working good by analyze the environment where the business is set up, whether to be enlarged to be installed. Grounded on this analysis, they have to determine whether the business should be sustained to continue or not. For the firms go on, it's important to generate a business plan; to deliver a strategic management and competitive advantage, to know how things will go on, to analyze and to transmute everything in reality.

Knowledge is a critical element that change the competition model of business from time to time, and it has been recognized as one of the most important success factors to an organization in many key aspects, such as innovation, quality and so on (Gholipour, Jandaghi, \& Hosseinzadeh, 2010; Ooi, 2009; Wang \& Wu, 2011). Innovation appears as the most significant and critical resources for the organization to prosper in a competitive environment. Firm Management (employer and employee) have to try to be innovative. There best should be put forward to pay full concentration not only in product innovation, marketing mix, market and services, but also they need to increase improvement in the research and development ability on market and product, and pay attention to the management of the enterprise intellectual capital. Intellectual capital is a very important element for the success of organizations to get a competitive advantage

Eventually, Small business research, though rapidly progressing still lacks a theoretical grounded understanding of the factors underlying business research. Especially the case within the context of Nigeria, whereas business, academic research is incipient and lackluster, where statistics about SMEs are not updated. The paper will contribute to the consistency of knowledge, serving as a reference point in assisting the entrepreneurs, policy makers, and provide insight on the problems of SMEs, and what influences their performance in a competitive environment.

\section{References:}

Analoui, F., \& Karami, A. (2003). Strategic management in small and medium enterprises. Australia: Thomson Learning.

Bahiti, R. (2008). ICT in small and medium enterprises (Case of Albania). Epoka University Center for European Studies, 1, 184-207. Retrieved May 11, 2011, from http://ces.epoka.edu.al/icbs/14.pdf

Bannock, G. (1981). The economics of small firms: return from the wilderness. Oxford: Blackwell.

Barney, J. (1991). Firm resources and sustained competitive advantage. Journal of Management, 17(1), 99-120. http://dx.doi.org/10.1177/014920639101700108

Barney, J. B. (2001). Is the resource-based "view" a useful perspective for strategic management research? Yes. The Academy of Management Review, 26(1), 41.

Dess, G. G., Lumpkin, G. T., \& Eisner, A. B. (2007). Strategic management: Text and cases. Boston: McGraw-Hill/Irwin.

Eniola, A. A. (2014). The role of SME firm performance in Nigeria. Arabian Journal of Business and Management Review, 3(12), 33-47. Retrieved March 30, 2014, from www.arabianjbmr.com/pdfs/OM_VOL_3_(12)/title

Epure, M. L. (2009, January 1). The branding process assessment of Romanian SMEs. (Report). Annals of DAAAM \& Proceedings, 20, 1.

Garnsey, E. (2002). Growth of new ventures: Analysis after Penrose. The growth of the firm: The legacy of Edith Penrose (pp. 101-125). Oxford: Oxford University Press.

Greiner, L. E. (1972). Evolution and revolution as organizations grow. Harvard Business Review, 50(4), 37-46.

Greiner, L. E. (1997). Evolution and revolution as organizations grow: A company's past has clues for management that are critical to future success. Family Business Review, 10(4), 397-409. http://dx.doi.org/10.1111/j.1741-6248.1997.00397.x 
SME firms performance in Nigeria: Competitive advantage and its impact

Harrision, N. J., \& Watson, T. (1998). The Focus for innovation in small and medium service enterprises.

Conference Proceedings of the 7th Annual Meeting of the Western Decision Sciences Institute, 7-11, 04.

Hill, C. L., \& Jones, G. R. (1998). Strategic management theory, An integrated approach (4th ed.). Boston, New York: Houghton Mifflin Company.

Hill, C. W., \& Jones, G. R. (2013). Strategic management: an integrated approach (10th ed.). Mason, OH: South-Western, Cengage Learning.

Jasra, M., Khan, A., Hunjra, I., Rehman, A. U., \& Azam, I. (2011). Determinants of business success of small and medium enterprises. International Journal of Business and Social Science, 2(20), 274-280.

Jennings, P., \& Beaver, G. (1997). The Performance And Competitive Advantage Of Small Firms: A

Management Perspective. International Small Business Journal, 15(2), 63-75. http://dx.doi.org/10.1177/0266242697152004

Jeronimo, T. B., \& Medeiros, D. D. (2012). The Mature of Strategic Business of Small and Medium-Sized High-Tech Companies in Brazil. International Journal of Business, Humanities \& Technology, 2(5), 143.

Keskin, H., \& Senturk, C. (2010). The importance of small and medium - sized enterprises (SMEs) in the economies: SWOT analyses of the SME sector in Turkey and Albani. Nigde University Journal of Economics and Administrative Sciences, 3(1), 116-132.

Khalique, M., Isa, A. H., \& Shaari, J. A. (2012). Challenges faced by Pakistani pharmaceutical industry: An intellectual capital perspective. International Journal of Research Studies in Management, 1(1), 39-45. http://dx.doi.org/10.5861/ijrsm.2012.v1i1.27

Kraja, B., \& Osmani, E. (2013). Competitive advantage and its impact in small and medium enterprises (SMEs) (Case Of Albania). European Scientific Journal, 9(16), 76-85. Retrieved March 24, 2014, from http://www.eujournal.org/index.php/esj/article/view/1137/1153

Kume, V., \& Leskaj, E. (2010). Strategic management aspects in Albanian companies. Scientific Annals of the 'Alexandru Ioan Cuza' University of Ias, 57, 353-368.

Lynch, R. (2000). Corporate strategy (2nd ed.). Harlow: Pearson Education

O'farrell, P. N., \& Hitchens, D. M. (1988). Alternative theories of small-firm growth: a critical review. Environment and Planning A, 20(10), 1365-1383. http://dx.doi.org/10.1068/a201365

Ovidijus, J. (2013, October 14). Resource-based view. strategic management insight. Retrieved January 21, 2014, from http://www.strategicmanagementinsight.com/topics/resource-based-view.html

Penrose, E. T. (1959). The theory of the growth in the firm. Oxford: Blackwell.

Penrose, E. T. (1985). The theory of the growth of the firm twenty-five years after. Uppsala: Universitetet.

Penrose, E. T., \& Pitelis, C. (2002). The growth of the firm: the legacy of Edith Penrose. Oxford: Oxford University Press.

Penrose, E. T., \& Pitelis, C. N. (2009). The theory of the growth of the firm (4th ed., rev. ed.). Oxford: Oxford University Press.

Porter, M. (1985). Competitive advantage. New York: The Free Press.

Porter, M. E. (1980). Competitive strategy: Techniques for analyzing industries and competitors. New York: Free Press.

Porter, M. E. (1990). The competitive advantage of nations. New York: Free Press.

Reid, M. G., \& Garnsey, E. (1996). Innovative management in small hitech firms: Building on experience, ESRC research programme on innovation. Cranfield: Cranfield University.

Rothaermel, F. T. (2013). Strategic management: concepts \& cases. New York: McGraw-Hill Irwin.

Storey, D. J. (1982). Entrepreneurship and the new firm. London: Croom Helm.

Storey, D. J. (1994). Understanding the small business sector. London: Routledge.

This Day Newspaper online. (2012, July 20). FG Releases First National Survey on SMEs Survey shows 99 per cent of firms are micro enterprises. This Day Live. Retrieved October 6, 2013, from http://www.thisdaylive.com/articles/fg-releases-first-national-survey-on-smes-survey-shows-99-per-cen t-of-firms-are-micro-enterprises/120425/

Wang, H., \& Wu, C. (2011). Green growth as the best choice for Chinese small and medium enterprises in 
Eniola, A. A. \& Ektebang, H.

sustainable development. Asian Social Science, 7(5), p81. http://dx.doi.org/10.5539/ass.v7n5p81

Wernerfelt, B. (1984). A resource-based view of the firm. Strategic Management Journal, 5(2), 171-180. http://dx.doi.org/10.1002/smj.4250050207

Wickham, P. A. (1998). Strategic entrepreneurship: A decision-making approach to new venture creation and management. London: Pitman.

Wickham, P. A. (2001). Strategic entrepreneurship: A decision-making approach to new venture creation and management (2nd ed.). Harlow: Financial Times Prentice Hall.

Wickham, P. A. (2006). Strategic entrepreneurship: A decision-making approach to new venture creation and management . Harlow: Pearson Education.

Zaridis, A. D. (2009). Competitive advantage and its sources in an evolving market. AIP Conference Proceedings, 1148, 917-921. http://dx.doi.org/10.1063/1.3225468 